\title{
Assessment of Knowledge and Fear of Scabies in a Saudi Population
}

\author{
Ahmad S Alharthi ${ }^{1}$ \\ Mohammed A Alsofyani ${ }^{2}$ \\ Wedd K Alharthi ${ }^{3}$ \\ Shaimaa A Alsalmi ${ }^{3}$ \\ Atheer S Altalhi ${ }^{3}$ \\ Khaled A Alswat ${ }^{4}$ \\ 'Department of Otorhinolaryngology - \\ Head and Neck Surgery, Taif University, \\ Taif, Saudi Arabia; ${ }^{2}$ Department of Family \\ Medicine, Ministry of Health, Taif, Saudi \\ Arabia; ${ }^{3}$ School of Medicine, Taif \\ University, Taif, Saudi Arabia; \\ ${ }^{4}$ Department of Medicine, School of \\ Medicine, Taif University, Taif, Saudi \\ Arabia
}

Background and Objectives: Scabies is a common contagious parasitic dermatological illness. In 2017, WHO recognized scabies as a neglected tropical disease. The aim of the present research was to assess the level of knowledge and fear of scabies among the Saudi population.

Methods: This is a cross-sectional online study conducted in the western region of Saudi Arabia from January to September 2019. We used a validated, 12-questions questionnaire to assess the scabies knowledge and the Fear of Scabies Scale-10 (FSS-10) to determine the level of fear toward scabies.

Results: A total of 3778 respondents were included with majorities of them being female and between the age of 15-30 years. About $93.3 \%$ of the respondents were considered to have good level of knowledge towards scabies and those were more likely to be females, live in an urban area, have heard about scabies in the past, younger in age, achieved higher educational level, and work for the medical and general education sector (all $\mathrm{P}<0.001$ ). The total possible scores ranging from 10 (less fear) to 40 (greater fear). The mean total FSS-10 score was $33 \pm 4.46$ with $58.3 \%$ of them were considered to have greater fear and those were more likely to be female, younger in age, educated with higher educational degree, work for the general education sector and medical and, but less likely to be unemployed (all $\mathrm{P}<0.001$ ). Partial correlation adjusting for potential confounders showed significant positive correlation between FSS-10 score and the scabies knowledge score $(\mathrm{r}=0.152, \mathrm{P}<0.001)$.

Conclusion: Despite the good level of scabies knowledge, the level of fear towards scabies is high. Further educational programs recommended decreasing the negative effect of scabies on the community and the individuals' quality of life.

Keywords: scabies, knowledge, fear, skin, infection, Saudi

\section{Introduction}

Scabies is a contagious parasitic dermatological disease caused by the microscopic mite, Sarcoptes scabiei variety hominis. ${ }^{1}$ Scabies is transmitted by either direct or indirect contact through sharing towels, bedding, clothing, or any other objects. $^{2}$ So, scabies transmission can be limited by avoiding skin to skin contact, avoiding sharing personal devices, and improving personal hygiene, especially in crowded places. ${ }^{3}$ The most common symptom of scabies is pruritus, which is especially aggravated at night. Also, it might present with a papular rash and excoriations. ${ }^{4,5}$ The scabies burrow is a pathognomonic sign that is useful for the definitive diagnosis of classical Scabies. ${ }^{6}$ But Scabies not always present in the classical type. The non-classical types include
Correspondence: Ahmad S Alharthi Department of Otorhinolaryngology Head and Neck Surgery, Taif University, P.O. Box II099, Taif, 21944, Saudi Arabia Tel +966595677880

Emaila7mad.al0rabi@gmail.com 
Crusted scabies, Nodular Scabies, Clean man scabies, infants and newborn Scabies, and Scabies incognito. Crusted Scabies is observed mainly in immunecompromised patients. It is characterized by hyperkeratotic skin crust that appears on the palms, soles, extensor surfaces, and under the fingernails. ${ }^{7}$

Nodular Scabies is caused by a hypersensitivity reaction to scabies mites. ${ }^{8}$ It appears as persistent pruritic nodules commonly in the axilla, Genitalia, and scrotum. ${ }^{9,10}$

Clean man scabies occurs in a clean environment and not secondary to lousy hygiene. It is present as pruritus without scabetic lesions. Infants and newborn scabies characterized by vesicles and pustules in palms and soles. Also, it is rare to see the burrows except in the scalp and face. The last atypical type is Scabies incognito. This type occurred in a patient who used topical or systemic corticosteroid, which relieves itching. So, it is not easy to diagnose. ${ }^{11}$

Scabies can be diagnosed by skin scrapings, a burrow ink test, and dermatoscopy. ${ }^{5}$

The recommended treatment of scabies is oral ivermectin, benzyl benzoate lotion, and permethrin cream. ${ }^{3}$ Scabies is correlated with an increase in morbidity and mortality through progress to secondary bacterial infections, then sepsis, which is a life-threatening condition. ${ }^{5,12}$ Otherwise, scabies can lead to depression and insomnia. The risk of scabies is not restricted to health problems, as it also affects social status, work attendance, and leads to high financial costs. $^{5,13}$

Scabies is a common dermatological disease and a growing public health concern. Over recent years, scabies has affected about 300 million people worldwide. ${ }^{14}$ In 2017, the World Health Organization recognized scabies as a neglected tropical disease. ${ }^{15,16}$ Evidence suggests that the highest prevalence of scabies is present in low-income areas. ${ }^{17}$ Also, its prevalence is high in Middle Eastern countries, such as Iran, Lebanon, Egypt, and Saudi Arabia. ${ }^{18-21}$ Because of its high prevalence in the poor, crowded areas, scabies is considered one of the most significant challenges to the Saudi Ministry of Health. ${ }^{21}$ The outbreak of scabies in the western region of Saudi Arabia was a critical event of 2018, where the Saudi Ministry of Health recorded more than 1000 cases among the schoolchildren in
Makkah city. ${ }^{22}$ In 2000, 18 workers at the crowded fields in Jeddah city were diagnosed to have scabies. ${ }^{21}$ Because of the hot weather, the recurrence rate of scabies is high in the western region of Saudi Arabia. $^{23}$

In 2019, the Indian education program of scabies was initiated, which included 50 mothers. Its results showed significantly inadequate knowledge about scabies among the respondents before this education program. ${ }^{24}$ Guinea-Bissau's study in 2018 reported that there is a misunderstanding among the population regarding the causes and transmission routes of scabies, and the role of personal hygiene as a preventive measure against it. ${ }^{13}$ Likewise, a cross-sectional study among the Pakistani population also showed a significant lack of awareness about scabies. ${ }^{25}$

A previous study assessed knowledge, attitude, and practice of scabies among Saudi medical students, which showed that they have a good knowledge level regarding scabies. ${ }^{26}$ Another study conducted among the general population in Saudi Arabia to assess their awareness about scabies and its results showed that their awareness was satisfactory regarding the ways of transmission and symptoms of scabies. However, there is inadequate awareness of the preventive methods of scabies. ${ }^{27}$

Recently, after the spread of the disease, many Saudi people felt overwhelmed and panicked. This panic was driven by unawareness of the disease, the possibility of death secondary to the disease, and whether it can be prevented or cured. ${ }^{22}$ Nevertheless, few studies have addressed the issue of scabies in Saudi Arabia. Here, this study provides a new insight about knowledge and fears of scabies disease among the Saudi population.

\section{Materials and Methods Study Area}

We conducted a cross-sectional study from January 31 st until September 30th, 2019 in the western region of Saudi Arabia to assess the knowledge of scabies and scabies fearing scale among the general population. Anyone above the age of 18 years was invited to participate in this study through an online invitation. The study proposal was submitted to the Taif University 
School of Medicine Ethical Committee and was approved (number 39-36-0047). All participants agreed to participate in this study before filling the questionnaire and an online informed consent was used as well as this study was conducted in accordance with the Declaration of Helsinki.

\section{Collecting Data}

The data were collected via electronic distribution of validated questionnaire using Google forms. The link was circulated through different social media apps and it was restricted to single response per user. The questionnaire was divided into three parts. The first part included questions about the baseline characteristics of the respondents, including the socio-demographic data, educational level, residency, occupational field, and personal experience about having scabies or living with someone who was diagnosed with scabies.

The second part included 12 questions to assess scabies knowledge; ${ }^{23}$ each question has three marks if answered (correct $=3$, might $=2$, wrong $=1$ ), and the maximum total mark was 36 . The level of respondent's knowledge was considered good if the score was more than or equal to 27 , moderate if between 15-26, and poor if 14 or below.

The third part of the questionnaire focused on the scabies fearing scale ${ }^{31}$ to assess the level of fear and discomfort of the population towards scabies, which can help to determine the ideal psychosocial support along with education programs about scabies. The Fear Scabies Scale (FSS-10 scale) was used to determine the level of fear/discomfort towards scabies. This scale includes 10 questions with each to be answered with strongly agree, agree, disagree, or strongly disagree on a four-point scale, with total possible scores ranging from 10 (less fear) to 40 (greater fear). Those who scored $<33$ was considered to have less fear while those who scored $\geq 33$ was considered to have greater fear. We excluded the incomplete responses.

\section{Data Analysis}

All completed online questionnaires were collected in an Excel spreadsheet and verified, coded and entered to the Statistical Package for the Social Sciences program (SPSS) version 21 which was used to analyze the data.
The descriptive statistical analysis in the SPSS program was employed to represent the demographic data and the distribution of knowledge by frequencies and percentages. Also, means and standard deviations (SD) were used to calculate the total fear of scabies scale score-10. Chi-square test was used to compare the level of knowledge and FSS-10 according to the demographic data. Partial correlation was used to evaluate relationship between FSS-10 and level of knowledge. We considered $\mathrm{P}$-value $\leq 0.05$ to be statistically significant.

\section{Results}

A total of 3778 respondents participated in this study with majorities of them were female and between the age of 15-30 years (Table 1). More than $90 \%$ of the sample live in urban area. Respondents mostly work for the general educational sector followed by medical sector while the least percent of them work for the military section. Most of the respondents were college students and has bachelor's degree while only $1.3 \%$ were illiterate.

Overall, 93.3\% of the respondents were considered to have a good level of knowledge towards scabies (Figure 1). Most respondents answered all the questions correctly, except one question about the signs and symptoms of scabies where only $22.1 \%$ of respondents answered it correctly. The question of "Can scabies be harmful to the health of skin?" was the most correctly answered question (Table 2).

Regarding the respondents' level of knowledge and when compared to those with moderate knowledge, those with good knowledge were more likely to be females $(\mathrm{P}<0.001)$, live in an urban area $(\mathrm{P}<0.001)$, have heard about scabies in the past $(\mathrm{P}<0.001)$, younger in age $(\mathrm{P}<0.001)$, achieved higher educational level $(\mathrm{P}<0.001)$, work for the medical and general education sector $(\mathrm{P}<0.001)$, but were less likely to have an affected family member with scabies ( $P$ $<0.001)$ and to have an affected family member with scabies $(\mathrm{P}<0.001)$ (Table 3$)$.

The total mean score of FSS-10 was $33 \pm 4.5$ which indicated a direction toward a higher and greater fears (Table 4). The respondents highest score mean was for the statement, "I would avoid interaction with others if I had scabies" followed by the statement of "I am afraid of contracting scabies". While the lowest score mean was for 
Table I Demographic Data of the Respondents

\begin{tabular}{|c|c|c|c|}
\hline \multicolumn{2}{|l|}{ Variables } & \multirow{2}{*}{$\begin{array}{c}\text { Frequency } \\
691\end{array}$} & \multirow{2}{*}{$\frac{\text { Percentage (\%) }}{18.3}$} \\
\hline Gender & Male & & \\
\hline & Female & 3087 & 81.7 \\
\hline \multirow[t]{2}{*}{ Residence } & Urban area & 3509 & 92.9 \\
\hline & Rural area & 269 & 7.1 \\
\hline $\begin{array}{l}\text { I have heard about scabies disease } \\
\text { before }\end{array}$ & Yes & 3487 & 92.3 \\
\hline Affected family member with Scabies & Yes & 360 & 9.5 \\
\hline \multirow[t]{4}{*}{ Age (years) } & $15-30$ & 2146 & 56.8 \\
\hline & $31-45$ & 1112 & 29.4 \\
\hline & $46-60$ & 468 & 12.4 \\
\hline & $>60$ & 52 & 1.4 \\
\hline \multirow[t]{7}{*}{ Educational level } & Illiterate & 47 & 1.2 \\
\hline & Elementary school & 48 & 1.3 \\
\hline & Intermediate school & 180 & 4.8 \\
\hline & High student & 761 & 20.1 \\
\hline & Bachelor's degree & 2567 & 67.9 \\
\hline & Master's degree & 114 & 3 \\
\hline & Ph.D. & 61 & 1.6 \\
\hline \multirow[t]{5}{*}{ Occupational field } & General educational sector & 1803 & 47.7 \\
\hline & Medical sector & 958 & 25.4 \\
\hline & Commercial sector & 252 & 6.7 \\
\hline & Military sector & 152 & 4 \\
\hline & Unemployed & 316 & 16.2 \\
\hline
\end{tabular}

the statement, "I would try to seek immediate medical help if I had scabies "followed by the statement of "I would feel ashamed if I had scabies".

$58.3 \%$ of the respondents were considered to have greater fear based on the mean total FSS-10 score. Compared to those with less fear, those with greater fear were more likely to be female $(\mathrm{P}<0.001)$, younger in age $(\mathrm{P}<0.001)$, educated with higher educational degree $(\mathrm{P}$ $<0.001$ ), work for the general education sector and medical sector but less likely to be unemployed ( $\mathrm{P}<0.001$ ), while who live in urban area $(p=0.159)$, have heard about scabies in the past $(\mathrm{P}=0.308)$ and have an affected family member with scabies $(P=0.136)$ showed no statistical significant (Table 5).

Partial correlation adjusting for age, gender, residence area, occupation and education showed significant positive correlation between FSS-10 score and the scabies knowledge score $(\mathrm{r}=0.152, \mathrm{P}<0.001)$.

\section{Discussion}

In the present study, we attempted to assess the level of knowledge of scabies during an endemic with emphasis on the fear of contracting scabies. The general risk factors of scabies are immunocompromised patients, 


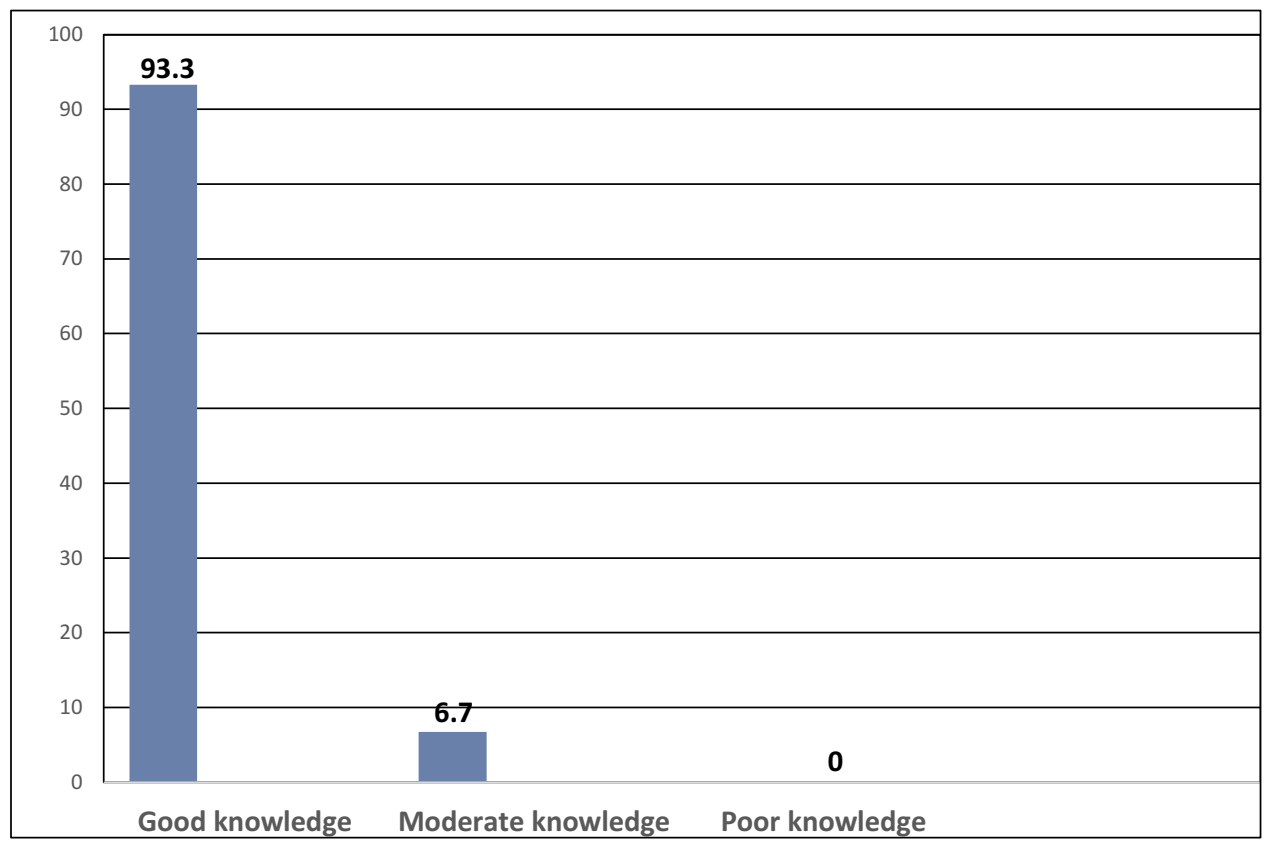

Figure I Distribution of the respondents according to their knowledge level about scabies.

poverty, and overcrowding. However, in Makkah 2018 outbreak, none of these risk factors were significant among the infected patients who are mostly Saudi healthy individuals which made the lack of knowledge the suggested predisposing factor in that outbreak. ${ }^{28}$ Here, the inclusive results indicate that the knowledge towards scabies is significantly high in our findings compared to other studies conducted in low-income endemic countries such Pakistan, India, Guinea-Bissau and Indonesia. ${ }^{13,24,25,29}$ Also, it is higher than that of the studies conducted in Saudi Arabia previously. This knowledge relies mostly on the awareness campaigns about Scabies on social media by the Saudi Ministry of health. ${ }^{30}$ Likewise, the knowledge and FSS-10 scale are both greater in our findings than that of the US college students. ${ }^{31}$

This study questionnaire, the lowest level of knowledge was in the clinical presentation of Scabies, where $22 \%$ of the respondents answered it incorrectly. However, almost $76 \%$ have answered overall questions correctly. Comparably, a similar study conducted among Saudi medical students which showed high awareness level among them while $21.6 \%$ of them misstated in answering the "common feature of scabies" questions. ${ }^{26}$ This result is also consistent with data obtained in study conducted among Al-Madinah Almunawarh population which showed enough levels of the general knowledge regarding the various aspects of Scabies. $^{27}$ By contrast, a study conducted in Indonesia reported low knowledge about the causative organism and the preventive measures of scabies. ${ }^{29}$ Singg S. (2015) showed that $94 \%$ of college students of United States had poor awareness of Scabies. ${ }^{31}$

The present results showed statistically significant difference between the level of knowledge and all the demographic data that has been studied, including gender, residency, educational level and occupational field. It has been reported that the knowledge and attitude towards scabies is good among the medical and nursing student's community. ${ }^{26,32}$ Our study showed similar findings were Bachelor's degree holders, general educators and medical professionals have greater knowledge compared with the rest of the respondents, which can be explained by the fact that the more urban and educated are the more likely to be knowledgeable. 
Table 2 The Level of Knowledge Questionnaire with All Answers

\begin{tabular}{|c|c|c|c|}
\hline Question About knowledge & Choices & Frequency & $\begin{array}{l}\text { Percentage } \\
\text { (\%) }\end{array}$ \\
\hline \multirow[t]{2}{*}{ I-Have you ever heard about scabies disease? } & $*$ Yes & 3487 & 92.3 \\
\hline & No & 291 & 7.7 \\
\hline \multirow[t]{3}{*}{ 2-What is its cause (etiology)? } & *Sarcoptesscabiei & 2883 & 76.3 \\
\hline & Germs & 817 & 21.7 \\
\hline & Scratching & 77 & 2 \\
\hline \multirow[t]{3}{*}{ 3-What are its signs and symptoms? } & *Small to large spots which are reddish and wet & 835 & 22.1 \\
\hline & Itching at night and feeling hot & 2856 & 75.6 \\
\hline & Pus containing vesicles & 87 & 2.3 \\
\hline \multirow[t]{3}{*}{ 4-Which Parts of body are affected with scabies? } & $\begin{array}{l}\text { *Between fingers, armpits, waist, genitals, elbows, and } \\
\text { wrists }\end{array}$ & 2989 & 79.1 \\
\hline & Parts that are often being covered & 691 & 18.3 \\
\hline & Mostly at the genital area & 98 & 2.6 \\
\hline \multirow[t]{3}{*}{ 5- What is the mode of transmission of scabies disease? } & $\begin{array}{l}\text { *Skin to skin contact and through clothes, towels, bed } \\
\text { linens, and Other things used by the patient }\end{array}$ & 3331 & 88.2 \\
\hline & Through skin contact only & 275 & 7.3 \\
\hline & Through clothes and bed linens only & 172 & 4.6 \\
\hline \multirow[t]{3}{*}{ 6-Which age groups can be infected with scabies? } & *All age groups but it is more common in teenagers & 3102 & 82.1 \\
\hline & Teenagers only & 130 & 3.4 \\
\hline & Certain age groups only & 546 & 14.5 \\
\hline \multirow{3}{*}{$\begin{array}{l}\text { 7- Is exchanging clothes with an infected person } \\
\text { associated with increased transmission of scabies? }\end{array}$} & *Yes, it is & 3337 & 88.3 \\
\hline & Only when the immunity is low & 340 & 9 \\
\hline & No, it is not & 101 & 2.7 \\
\hline \multirow[t]{2}{*}{ 8-Can scabies be harmful to the health of skin? } & *Yes & 3514 & 93 \\
\hline & No & 264 & 7 \\
\hline \multirow[t]{3}{*}{ 9-Does the patient need to be quarantined? } & *No, the patient just needs regular treatment & 1515 & 40.1 \\
\hline & $\begin{array}{l}\text { No, but persons should keep a distance from the } \\
\text { patient }\end{array}$ & 1030 & 27.3 \\
\hline & Yes, the patient needs to be quarantined & 1233 & 32.6 \\
\hline \multirow[t]{3}{*}{$\begin{array}{l}\text { 10-What should we do to break the chain of scabies } \\
\text { disease? }\end{array}$} & $\begin{array}{l}\text { *Disinfection of clothing, bed linens and administration } \\
\text { of treatment simultaneously }\end{array}$ & 2932 & 77.6 \\
\hline & Keep a distance with others when being infected & 601 & 15.9 \\
\hline & Regular treatment only & 245 & 6.5 \\
\hline \multirow{2}{*}{$\begin{array}{l}\text { II-Does drying mattress and pillows prevent scabies } \\
\text { transmission? }\end{array}$} & $*$ Yes & 3178 & 84.1 \\
\hline & No & 600 & 15.9 \\
\hline
\end{tabular}

(Continued) 
Table 2 (Continued).

\begin{tabular}{|l|l|l|l|}
\hline Question About knowledge & Choices & Frequency & $\begin{array}{l}\text { Percentage } \\
\text { (\%) }\end{array}$ \\
\hline 12-How can scabies be prevented? & $\begin{array}{l}\text { Bath 2 times per day with soap and avoid direct contact } \\
\text { with the patients }\end{array}$ & 1364 & 36.1 \\
\cline { 2 - 5 } & Bath 2 times per day and keep the cleanliness of clothes & 767 & 20.3 \\
\cline { 2 - 5 } & $\begin{array}{l}\text { *Keep clothes, towels and bed linens from being } \\
\text { contaminated with scabies patients }\end{array}$ & 1647 & 43.6 \\
\hline
\end{tabular}

Note: *The correct answer.

Table 3 Comparison of the Respondents According to Their the Level of Knowledge

\begin{tabular}{|c|c|c|c|c|c|c|}
\hline & & \multicolumn{2}{|c|}{ Good Knowledge } & \multicolumn{2}{|c|}{ Moderate Knowledge } & \multirow[t]{2}{*}{$P$ value } \\
\hline & & Frequency & Percentage (\%) & Frequency & Percentage (\%) & \\
\hline \multicolumn{2}{|c|}{ Number of the participants } & 3526 & 93.3 & 252 & 6.7 & $\mathrm{n} / \mathrm{a}$ \\
\hline \multirow[t]{2}{*}{ Gender } & Male & 616 & 17.5 & 75 & 29.8 & \multirow[t]{2}{*}{$<0.001$} \\
\hline & Female & 2910 & 82.5 & 177 & 70.2 & \\
\hline \multirow[t]{2}{*}{ Residence } & Urban area & 3299 & 93.6 & 210 & 83.3 & \multirow[t]{2}{*}{$<0.001$} \\
\hline & Rural area & 227 & 6.4 & 42 & 16.7 & \\
\hline \multicolumn{2}{|c|}{ I have heard about scabies disease before } & 3329 & 94.4 & 158 & 62.7 & $<0.001$ \\
\hline \multicolumn{2}{|c|}{ I have an affected family member with Scabies } & 291 & 8.3 & 69 & 27.4 & $<0.001$ \\
\hline \multirow[t]{4}{*}{ Age (years) } & $15-30$ & 2037 & 57.8 & 109 & 43.3 & \multirow[t]{4}{*}{$<0.001$} \\
\hline & $31-45$ & 1016 & 28.8 & 96 & 38.1 & \\
\hline & $46-60$ & 432 & 12.2 & 36 & 14.2 & \\
\hline & $>60$ & 41 & 1.2 & II & 4.4 & \\
\hline \multirow[t]{7}{*}{ Educational level } & Illiterate & 33 & 0.9 & 14 & 5.6 & \multirow[t]{7}{*}{$<0.001$} \\
\hline & Elementary school & 38 & I.I & 10 & 4.0 & \\
\hline & Intermediate school & 159 & 4.6 & 21 & 8.2 & \\
\hline & High student & 701 & 19.9 & 60 & 23.8 & \\
\hline & Bachelor's degree & 2431 & 68.9 & 136 & 54.0 & \\
\hline & Master's degree & 106 & 3.0 & 8 & 3.2 & \\
\hline & Ph.D. & 58 & 1.6 & 3 & 1.2 & \\
\hline \multirow[t]{5}{*}{ Occupational field } & General educational sector & 1714 & 48.6 & 89 & 35.3 & \multirow[t]{5}{*}{$<0.001$} \\
\hline & Medical sector & 921 & 26.2 & 37 & 14.7 & \\
\hline & Commercial sector & 220 & 6.2 & 32 & 12.7 & \\
\hline & Military sector & 124 & 3.5 & 28 & 11.1 & \\
\hline & Unemployed & 547 & 15.5 & 66 & 26.2 & \\
\hline
\end{tabular}


Table 4 Distribution of Respondents Based on the Fear of Scabies Scale

\begin{tabular}{|c|c|}
\hline Fear of Scabies Scale-10 (FSS-I0) Item* (Mean ISD) & Mean \pm SD \\
\hline I-I am afraid of contracting scabies & $37.2 \pm 5.6$ \\
\hline 2-I would feel ashamed if I had scabies & $25.3 \pm 12.8$ \\
\hline 3-If I had scabies, I would feel that I want to hide this disease & $33.4 \pm 10.1$ \\
\hline 4-I would avoid interaction with others if I had scabies & $38.3 \pm 5.5$ \\
\hline 5-I would try to seek immediate medical help if I had scabies & $25.4 \pm 12.6$ \\
\hline 6-Having scabies would greatly restrict my life & $35.5 \pm 8.6$ \\
\hline 7-I would avoid public bathrooms, theaters and others public places where I may be infected with scabies & $30.0 \pm 11.6$ \\
\hline 8-I will not afraid if I have scabies because all the treatment is available & $34.8 \pm 8.9$ \\
\hline 9-If I knew someone has scabies, I would stay away from him & $34.8 \pm 8.9$ \\
\hline 10-If I had scabies, I would let the others know & $35.3 \pm 7.4$ \\
\hline The total (FSS-10) weighted score mean & $33 \pm 4.5$ \\
\hline
\end{tabular}

Note:*The Fear of Scabies Scale-10 was adapted from: Singg S. Scabies Awareness and Fear of Scabies Scale-10. J Clin Case Stud. 2016;I(I):9-I0.3I Copyright: @ 2015 Singg S. Creative Commons Attribution License.

This study used the statements of FSS-10 scale to determine the level of fear/discomfort towards scabies. The results showed high fear scores, where the total mean score was $33 \pm 4.5$ out of 40 . In general, the statistically significant positive correlation between good level of knowledge and higher FSS-10 score may have been influenced by the social stigma of contracting scabies as the majority (38.28 \pm 5.52$)$ would avoid interaction with others if they had scabies. Since female and urban had a greater FSS-10 score than the others, it is probably due to these two variables were the more presentable and knowledgeable in our study. Similarly, Singg S. (2015) showed that females had greater FSS-10 than males. ${ }^{31}$

The impact of these data has shed a light on the burden of scabies on the community and the quality of life of the individuals. It negatively interferes with sleep due to itching. Also, it affects the individual's work, social activity and psychological health due to stigmatization and feelings of shame. ${ }^{13,33}$ According to Global Burden of Disease study 2015, scabies is considered as a significant health burden in the tropical regions. ${ }^{34}$ To prevent further outbreaks, it is recommended to raise community knowledge beside application of management guidelines. ${ }^{28}$ In COVID19 pandemic during 2020, the reported increase of the scabies incidence rate supports the importance of public awareness. ${ }^{35}$ It is recommended to conduct educational programs of scabies, its symptoms and transmission to high-risk groups to improve the prevention strategy.

\section{Limitations}

The current study has the following limitations. A low response from the males could affect the generalizability of the finding, the selection bias due to the web-based nature of the study, which is considered convenient sample.

Nonetheless, the strength point of this study is that it is the largest study in the western region of Saudi so far documenting the level of knowledge of scabies.

\section{Conclusion}

The most obvious finding to emerge from this study is that the level of fear and discomfort towards scabies is high, despite the good level of knowledge regarding the disease. Further educational programs are recommended to avoid the negative impact of scabies on the community and the quality of an individual's life. 
Table 5 Comparison of the Respondents According to Their Fear Scabies Scale Score

\begin{tabular}{|c|c|c|c|c|c|c|}
\hline & & \multicolumn{2}{|c|}{ Greater Fear } & \multicolumn{2}{|l|}{ Less Fear } & \multirow[t]{2}{*}{$P$ value } \\
\hline & & Frequency & $\begin{array}{l}\text { Percentage } \\
\text { (\%) }\end{array}$ & Frequency & $\begin{array}{l}\text { Percentage } \\
\text { (\%) }\end{array}$ & \\
\hline \multicolumn{2}{|c|}{ Number of the participants } & 2201 & 58.3 & 1577 & 41.7 & $\mathrm{n} / \mathrm{a}$ \\
\hline \multirow[t]{2}{*}{ Gender } & Male & 432 & 19.6 & 259 & 16.4 & \multirow[t]{2}{*}{$<0.001$} \\
\hline & Female & 1769 & 80.4 & 1318 & 83.6 & \\
\hline \multirow[t]{2}{*}{ Residence } & Urban area & 2036 & 92.5 & 1473 & 93.4 & \multirow[t]{2}{*}{0.159} \\
\hline & Rural area & 165 & 7.5 & 104 & 6.6 & \\
\hline \multicolumn{2}{|c|}{ I have heard about scabies disease before } & 2036 & 92.5 & $|45|$ & 92.1 & 0.308 \\
\hline \multicolumn{2}{|c|}{ I have an affected family member with Scabies } & 220 & 10 & 140 & 8.9 & 0.136 \\
\hline \multirow[t]{4}{*}{ Age (years) } & $15-30$ & 1301 & 59.1 & 845 & 53.6 & \multirow[t]{4}{*}{$<0.001$} \\
\hline & $31-45$ & 614 & 27.9 & 498 & 31.6 & \\
\hline & $46-60$ & 264 & 12 & 204 & 12.9 & \\
\hline & $>60$ & 22 & 1 & 30 & 1.9 & \\
\hline \multirow[t]{7}{*}{ Educational level } & Illiterate & 20 & 0.9 & 27 & 1.7 & \multirow[t]{7}{*}{$<0.001$} \\
\hline & Elementary school & 25 & I.I & 23 & 1.5 & \\
\hline & Intermediate school & 90 & 4.1 & 90 & 5.7 & \\
\hline & High student & 449 & 20.4 & 312 & 19.8 & \\
\hline & Bachelor's degree & $|52|$ & 69.1 & 1046 & 66.3 & \\
\hline & Master's degree & 70 & 3.2 & 44 & 2.8 & \\
\hline & Ph.D. & 26 & 1.2 & 35 & 2.2 & \\
\hline \multirow[t]{5}{*}{$\begin{array}{l}\text { Occupational } \\
\text { field }\end{array}$} & $\begin{array}{l}\text { General educational } \\
\text { sector }\end{array}$ & 1091 & 49.6 & 712 & 45.1 & \multirow[t]{5}{*}{$<0.001$} \\
\hline & Medical sector & 625 & 28.4 & 333 & 21.1 & \\
\hline & Commercial sector & 140 & 6.4 & 112 & 7.1 & \\
\hline & Military sector & 85 & 3.9 & 67 & 4.2 & \\
\hline & Unemployed & 260 & 11.8 & 353 & 22.4 & \\
\hline
\end{tabular}

\section{Ethical Approval and Consent}

The study was conducted in accordance with the Declaration of Helsinki. All participants agreed to participate before filling the questionnaire. The research project was approved by the research ethical committee at Taif university (Approval number 39-36-0047)

\section{Funding}

This project was supported by the Taif University Research Support Project Number (TURSP-2020/37), Taif University, P.O. Box 11099, 21944, Taif, Saudi Arabia.

\section{Disclosure}

The authors reported no conflicts of interest for this work.

\section{References}

1. Bernigaud C, Fang F, Fischer K, et al. Efficacy and pharmacokinetics evaluation of a single oral dose of afoxolaner against sarcoptes scabiei in the porcine scabies model for human infestation. Antimicrob Agents Chemother. 2018;62(9):1-12. doi:10.1128/AAC.02334-17

2. Alsyali Z, Alaithan A, Almubarak K, et al. A comprehensive review study on scabies and its associated impact on psycho-social health of an individual. Int J Contemp Res Rev. 2019;10(02):20700-20707. doi:10.15520/ijcrr.v10i02.674 
3. Salavastru CM, Chosidow O, Boffa MJ, Janier M, Tiplica GS. European guideline for the management of scabies. $J$ Eur Acad Dermatol Venereol. 2017;31(8):1248-1253. doi:10.1111/jdv.14351

4. Gunning K, Pippitt K, Kiraly B, Sayler M. Pediculosis and scabies: treatment update. Am Fam Physician. 2012;86(6):535-541.

5. Banerji A, Canadian Paediatric Society, First Nations, Inuit and Métis Health Committee. Scabies. Paediatrics \& Child Health. 2015;20 (7):395-398. doi:10.1093/pch/22.7.395

6. Ueda T, Katsura Y, Sasaki A, Minagawa D, Amoh Y, Shirai K. Grayedged line sign of scabies burrow. J Dermatol. 2021;48(2):190-198. doi:10.1111/1346-8138.15650

7. C V. Scabies and pediculosis in children. Indian J Pract Pediatr. 2008;IX(3):366-371.

8. Yanes DA, Faith EF. Nodular scabies: a persistent nodular eruption. Dermatol Online J. 2018;24(8):0-3.

9. Mittal A, Garg A, Agarwal N, Gupta L, Khare AK. Treatment of nodular scabies with topical tacrolimus. Indian Dermatol Online J. 2013;4(1):52-53. doi:10.4103/2229-5178.105486

10. Shanshal M. Post-scabietic mastocytoid nodules: a clinical and histopathological evaluation with new pearls. American Journal of Dermatology and Venereology. 2019. doi:10.5923/j.ajdv.20190803.01

11. Ahmed R. Indian Journal of Radiology. Radiology. 1946;47(6):620. doi:10.1148/47.6.620c

12. Lynar S, Currie BJ, Baird R. Scabies and mortality. Lancet Infect Dis. 2017;17(12):1234. doi:10.1016/S1473-3099(17)30636-9

13. Lopes MJ, da Silva ET, Ca J, et al. Perceptions, attitudes and practices towards scabies in communities on the Bijagós Islands, GuineaBissau. Trans R Soc Trop Med Hyg. 2020;114(1):49-56. doi:10.1093/ trstmh/trz102

14. Strong M, Johnstone PW. Interventions for treating scabies. Cochrane Database Syst Rev. 2007;(3). doi:10.1002/14651858. CD000320.pub2

15. Romani L, Whitfeld MJ, Koroivueta J, et al. Mass drug administration for scabies control in a population with endemic disease. $N$ Engl $J$ Med. 2015;373(24):2305-2313. doi:10.1056/nejmoa 1500987

16. Marks M, Toloka H, Baker C, et al. Randomized trial of community treatment with azithromycin and ivermectin mass drug administration for control of scabies and impetigo. Clin Infect Dis. 2019;68 (6):927-933. doi:10.1093/cid/ciy574

17. Kouotou EA, Nansseu JRN, Kouawa MK, Zoung-Kanyi Bissek AC. Prevalence and drivers of human scabies among children and adolescents living and studying in Cameroonian boarding schools. Parasit Vectors. 2016;9(1):4-9. doi:10.1186/s13071-016-1690-3

18. Dehghani R, Arani MG, Reza H, Arani S. Scabies contamination status in Iran: a review. International Journal of Epidemiologic Research. 2016;3(1):86-94.

19. Kawa N. Transmissible dermatological diseases affecting Syrian refugees in Lebanon. $J$ Refug Glob Heal. 2019;2(2):10-15. doi:10.18297/rgh/vol2/iss $2 / 4$

20. Salah Hegab D, Mahfouz Kato A, Ali Kabbash I, Maged Dabish G. Scabies among primary schoolchildren in Egypt: sociomedical environmental study in Kafr El-Sheikh administrative area. Clin Cosmet Investig Dermatol. 2015;8:105-111. doi:10.2147/CCID.S78287

21. Abou Zinada NY. Scabies in some workers living in crowded area, Jeddah, Saudi Arabia. J Egypt Soc Parasitol. 2000;30(1):325-328.
22. GDN Online Desk. KSA: 1038 cases of scabies diagnosed in Mecca. Published online 2018; 2021. Available from: http://www.gdnonline. com/Details/345923/1038-cases-of-scabies-diagnosed-in-Mecca. Accessed May 11, 2021.

23. Ahmed AE, Jradi H, Alburaikan DA, et al. Rate and factors for scabies recurrence in children in Saudi Arabia: a retrospective study. BMC Pediatr. 2019;19(1):1-6. doi:10.1186/s12887-019-15659

24. Handa S. Effectiveness of structured-teaching programme on knowledge and attitude regarding scabies among mothers of under-five children. Int J Adv Nurs Manag. 2019;7(4):339-343. doi:10.5958/ 2454-2652.2019.00079.9

25. Ali A. An endemic of scabies in Kahuta, Azad Kashmir. The study shows a lack of awareness of scabies; mass treatment is needed. J Pak Med Assoc. 2017;67(9):1432-1433.

26. Alshehri OM, Alharbi RA, Alsoraya BM. Assessment of knowledge, attitude and practice towards scabies among medical students in Kingdom of Saudi Arabia, 2018. Egypt J Hosp Med. 2018;73 (October):6897-6899. doi:10.21608/ejhm.2018.16940

27. Alharbi AHH, Mousa AN, Alrashidi RN, Alighadaf G, Aljohani AM. Awareness about scabies symptoms, transmission ways and prevention among population in Al-Madinah Almunawarh, Saudi Arabia. Pharmacophore. 2018;9(6):1-10.

28. Jastaniah MWA, Zimmo ZFK, Bakallah MWS, Hantoush MSS, Abdal-Aziz M. Clinical presentation and risk factors of increased scabies cases in the Western region of Saudi Arabia in 2016-2018. Saudi Med J. 2019;40(8):820-827. doi:10.15537/smj.2019.8.24360

29. Binti Mohd Yusof M, Fitri S, Damopolii Y. A study on knowledge, attitude and practice in preventing transmission of scabies in pesantren Darul Fatwa, Jatinangor. Althea Med J. 2015;2(1):131-137. doi:10.15850/amj.v2n1.448

30. MOH News. MOH News - statement of clarification on scabies and how to handle reported cases in Makkah - April 2018. Published online 2018; 2021. Available from: https://www.moh.gov.sa/en/ Ministry/MediaCenter/News/Pages/news-2018-04-03-006.aspx. Accessed May 11, 2021.

31. Singg S. Scabies Awareness and Fear of Scabies Scale-10. J Clin Case Stud. 2016;1(1):9-10. doi:10.16966/2471-4925.102

32. Bilal M, Abdell H, Medawi A, Ma M. Knowledge, attitude and practice in preventing transmission of scabies among nurses students at Sabia University College Jazan University. Austin Journal of Nursing \& Health Care. 2018. 2018;5(1):1-6.

33. Nair PA, Vora RV, Jivani NB, Gandhi SS. A study of clinical profile and quality of life in patients with scabies at a rural tertiary care centre. J Clin Diagn Res. 2016;10(10):WC01-WC05. doi:10.7860/ JCDR/2016/20938.8703

34. Karimkhani C, Colombara DV, Drucker AM, et al. The global burden of scabies: a cross-sectional analysis from the Global Burden of Disease Study 2015. Lancet Infect Dis. 2017;17(12):1247-1254. doi:10.1016/S1473-3099(17)30483-8

35. Kutlu Ö, Metin A. Relative changes in the pattern of diseases presenting in dermatology outpatient clinic in the era of the COVID-19 pandemic. Dermatol Ther. 2020;33(6):e14096. doi:10.1111/dth.14096 


\section{Publish your work in this journal}

The Journal of Multidisciplinary Healthcare is an international, peerreviewed open-access journal that aims to represent and publish research in healthcare areas delivered by practitioners of different disciplines. This includes studies and reviews conducted by multidisciplinary teams as well as research which evaluates the results or conduct of such teams or healthcare processes in general. The journal covers a very wide range of areas and welcomes submissions from practitioners at all levels, from all over the world. The manuscript management system is completely online and includes a very quick and fair peer-review system. Visit http://www.dovepress.com/testimonials. php to read real quotes from published authors. 